\title{
DOMESTIC VIOLENCE AGAINST WOMEN IN ALBANIA: A LEGAL AND SOCIOECONOMIC PERSPECTIVE
}

\author{
Asim Vokshi ${ }^{1}$, Jonida Rystemaj2 II \\ 1 - Tirana District Court, Tirana, Albania \\ 2 - University of Tirana, Tirana, Albania
}

\section{ABSTRACT}

Domestic violence is one of those social phenomena that because it is linked with the notion of conflict, have always been part of the human existence. It is generated in human interaction, and its causes have been studied by many scientists and other researchers of the field. The ability or inability of a person to resolve conflicts in a peaceful way influences his or her inclination toward violence. The failure to compromise and peacefully resolve domestic related problems is a predominant factor that feeds domestic violence. The aim of this paper is to explore the legal and socio-economic perspectives on domestic violence against women in Albania.

Domestic violence is an issue not only in developing countries, but also in consolidated and developed democracies. In Albania there have been made several efforts to create a legal framework in order to protect vulnerable groups targeted by domestic violence.

Albania is one of the developing countries of this world, where the culture of being strong and tough is still a strong value. Unfortunately many people link this quality with being violent toward others, irrespective of who they are (even family members). The need to dominate or other psychological factors play an important role in this context, along with models that one perceives as good to follow. Therefore culture is crucial in analyzing the factors that feed domestic violence. In recent years there has been a series of legal initiatives that have been enacted into law, and that deal with the question of domestic violence in Albania. But, the comparison with the EU countries shows that much needs to be done, in order to ameliorate the general situation of domestic violence.

\section{UDC \& KEYWORDS}

- UDC: 349 - DOMESTIC VIOLENCE " ALBANIAN LEGISLATION - SOCIAL PHENOMENA

\section{INTRODUCTION}

Domestic violence is one of those social phenomena that because it is linked with the notion of conflict, have always been part of the human existence. It is generated in human interaction, and its causes have been studied by many scientists and other researchers of the field. The ability or inability of a person to resolve conflicts in a peaceful way influences his or her inclination toward violence. The failure to compromise and peacefully resolve domestic related problems is a predominant factor that feed's domestic violence. The aim of this paper is to explore the legal and socio-economic perspectives on domestic violence against women in Albania.

From the very beginning we want to stress the fact that there is a substantial lack of coherent, updated, official and reliable data about the dimensions of domestic violence in Albania. Therefore, we will rely on a very limited pool of information

\section{I asimvokshi1@gmail.com}

" jrustemaj@gmail.com that comprises several reports from prestigious international organizations that operate in Albania and that have published studies and reports on this phenomenon and on a national survey published by the National Institute of Statistics in Albania (INSTAT) in 2009 (Haarr, Dhamo, 2009).

We can potentially assert that nobody is immune to domestic violence, in all of its forms, physical or psychological and we are contemporaneously "sad" and "pleased" to assert that domestic violence is not just an Albanian problem. We are "sad" because domestic violence is one of those social phenomena that does not render honor to a truly civilized country, but on the other hand we are "pleased" because domestic violence is a human problem that affects every country (developed or not), and not just Albania. The fight against domestic violence is an endeavor to become a better and more civilized people. Domestic violence is widespread across Europe, especially against women. "According to the Council of Europe, one European woman in four experiences domestic violence at some point in her life, and between $6-10 \%$ of women suffers domestic violence in a given year (TNS Report, 2010)." The situation in United States is comparable to that of Europe. According to her 1985 article Kathleen Waits stressed that in the U.S the situation of domestic violence against women was also severe. She acknowledged that:

"It is impossible to know the extent of wife abuse in our society. For many years, the problem was largely ignored, and the available information was so incomplete and disorganized that it was functionally useless. More recently, there have been some serious efforts to compile data, and the results are shocking. The battering of women is both widespread and dangerous. In any given year, at least one-tenth to one-fifth of American women are beaten by a man with whom they are intimately involved. This translates into some six million battered women in America each year. One woman in four will suffer abuse during the entire course of a given relationship." (Waits, 1985).

The above mentioned article is reflective of the present situation in our home country. Although the perception of substantial domestic violence in Albania is clear, the lack of data makes it difficult to assess its dimensions with certainty. The Albanian society is not more civilized than that of the main European countries or the U.S., and however it is likely that at least one in four women in Albania will experience at some point in their life the consequences of domestic violence.

\section{Domestic Violence against Women in Albania}

Waits (1985) claims that women in Albania as in other European countries play an important and crucial role in the society. After the Second World War, the Communist regime in Albania put in place reforms to create a substantial equality between man and women. Nevertheless, "during communism problems of domestic violence were considered taboo. Nobody dared to make them public. They were 
considered nonexistent, or in the best case the problem was dealt with by the Party organization. (UNICEF, 2000)" After 1991 Albania experienced rapid democratic changes toward a market economy. According to Baban (2003) most of the values of Communist Albania, now began to be considered as anti-values, and during this period unemployment went to unprecedented highs and the economy of most of the Albanian people was near extreme poverty. During this period of turmoil the question of domestic violence was given little attention. In an April 1996 report of the Minnesota Advocates for Human Rights on domestic violence in Albania it is acknowledged that:

"In interviews conducted by Minnesota Advocates for Human Rights, both men and women reported incidents of severe physical abuse of women by their husbands and intimate partners. A group of professional women in Tirana estimated that, based on their personal life experiences, more than half of the women in Albania have been beaten by their husbands or partners. In a recent survey conducted by the women's association "Refleksione" in Albania, more than $63 \%$ of the women surveyed reported that they had been abused by their husbands or partners." (Minnesota Advocates for Human Rights, 1996)

This report reflects the situation in the early years of democracy in Albania and provides a good idea of the magnitude of domestic violence against women during that period. In the report of Minnesota Advocates for Human Rights it is further stated:

"Police, prosecutors and judges treat domestic violence as a situation for which each party bears equal responsibility. They invariably try to persuade women to pardon their abusers at each stage of the legal process. The result of this focus on persuading the victim to do nothing rather than on the aggressive prosecution of the abuser is that the vast majority of women drop charges of assault before a trial is conducted." (Minnesota Advocates for Human Rights, 1996)

It is worth noting that the legislation against domestic violence in Albania in 1996 was almost absent. There has been only one official survey on domestic violence in Albania, done by the National Institute of Statistics of Albania (INSTAT) which was published on March 2009.

"INSTAT's survey was conducted between November and December 2007, and consisted of interviews with 2,590 women between the ages of 15 and 49 from Albania's 12 districts. The survey found that, of the women who participated in the survey,

- 50.6 percent had experienced emotional abuse;

- 39.1 percent had experienced psychological abuse;

- 31.2 percent had experienced physical violence; and

- 12.7 percent had experienced sexual violence." (Immigration and Refugee Board of Canada)

Another recent report by a Non-Profitable Organization in Albania analyzed the official data gathered by the General Directorate of the State Police in relation with the number of reported cases of domestic violence from 2009 to 2011. According to this report in $81 \%$ of the 5396 reported cases of domestic violence, the victim was a female (Data Centrum, 2012). The above mentioned data gives a clear hint about the prevalence of domestic violence against women in Albania.

\section{The Causes of Domestic Violence}

Domestic violence can be considered as old as the presence of humans on earth. As reveled by The Old Testament
(Genesis 4:8) Cain and Abel were brothers and children of Adam and Eve. Cain killed his brother Abel because he was jealous. Discussing the causes of domestic violence means after all, discussing the ability of human beings to resolve problems without resorting to violence. In this context we find it useful to speak of a problem as "a difference between the way things are and the way at least one person in a situation wants them to be. (McGowan, 2011)" Most of the domestic quarrels that lead to violence between family members have their roots exactly in this definition of a problem.

"Different studies have shown that there exist three categories of factors that stimulate domestic violence:

1) Macro-factors: culture influence, economy, different politics, demographic movements, patriarchal tradition, etc.

2) Micro-factors (at the family level): family relations, previous history of abuse during childhood, growing up in a family with an abusive environment, parent model in family, the large number of children in a family, family education, etc.

3) Factors on the personal level: mental health problems, personality disorders, alcohol and/or drug abuse, stress, low literacy levels, complex of inferiority, low level of control, lack of sensitivity, emotional dependency, personal experiences in family relations, etc. (Data Centrum, 2012)".

\section{Cultural Causes}

"A person's preferences are influenced by the environment in which he or she finds him- or herself. Context matters for predicting behavior." (Dallas, 2005). "[H]uman beings collectively construct or impose meaning upon behaviors this is what we mean by cultural systems of behavior." (Dallas, 2005). Changing the societal systems of understanding and belief is indeed a long journey. But, "novel behavior, once accepted into the cultural system, has the potential to alter, reconfigure and reconstruct the systems of cultural meaning by altering the understanding and weighing of the connections and patterns among behaviors (Dallas, 2005). In the survey that INSTAT has conducted in Albania and published in 2009, it "explains that domestic violence in Albania is connected to "patriarchal traditions," such as the "honor-and-shame system," and "hierarchal ordering with the family and intergenerational family control." (Immigration and Refugee Board of Canada).

In order to understand the social roots that feed domestic violence (from the part of the perpetrators) we need to understand the social norms that have governed the Albanian people through centuries. "Albanian [customary] law and traditions, which have ruled for centuries, have been very conservative as to the position of women. That "law" sanctioned inequality between men and women in economic, social and family issues." (Minnesota Advocates for Human Rights, 1996). The report of Minnesota Advocates for Human Rights identifies some of the cultural causes of the widespread acceptance of domestic violence, especially in the relation between husband and wife. They identify an old set of customary "law" called "Kanuni i Lekë Dukagjinit" or "Kanun" that used to apply especially in the North of Albania, and which regulated many aspects of peoples life, including family matters (Minnesota Advocates for Human Rights, 1996). This is "an unwritten law dating back to the Middle Ages." (Minnesota Advocates for Human Rights, 1996). "Although the Kanun does not have the force of law, it still influences 
attitudes and opinions in some parts of Albania." (Minnesota Advocates for Human Rights, 1996). Than in the report the authors illustrate some of the old Kanun norms that regulate the rights of man over women:

"The Kanun provides that men have the right to beat and publicly humiliate their wives if their wives disobey them. If the wife does not "conduct herself properly toward her husband," the man may "cut a ribbon from her belt or a lock of her hair" and leave her. The man is directed to cut his wife's hair, strip her nude, expel her from the house in the presence of relatives and then drive her with a whip through the entire village. The Kanun further provides:

If a husband beats his wife, he incurs no guilt . . . and her parents may not make any claims on him because of the beating. If a man beats his wife bloody, and she complains to her parents, the man must give an explanation. (Minnesota Advocates for Human Rights, 1996)

"Kanun" is just one part of a set of traditions, religious influences, and attitudes that through history have calcified the attitude of men toward women. Minnesota Advocates for Human Rights acknowledged in 1996 that "[t]he resulting intellectual and material backwardness provided the grounds for the underestimation and ill-treatment of women (suffice it to say that wife-beating was considered a normal and proper action." (Minnesota Advocates for Human Rights, 1996). At this point let's consider from a comparative perspective that "[t]he Anglo-American common law originally provided that a husband, as master of his household, could subject his wife to corporal punishment or "chastisement" so long as he did not inflict permanent injury upon her. During the nineteenth century, an era of feminist agitation for reform of marriage law, authorities in England and the United States declared that a husband no longer had the right to chastise his wife." (Siegel, 1996). It is easy to notice the similarities between these two sets of customary law.

\section{Economic Causes}

Domestic violence is sometimes influenced by the economic situation of a family. The chances of domestic violence increase when many people cohabit in a small area (Minnesota Advocates for Human Rights, 1996). This is true in large families that live in small houses where people do not have enough space privacy. Physical domestic violence against women is often manifested in an economic setting. Economic factors condition the choice of many women when they are faced with domestic violence. "[T]here are economic pressures such as unemployment and lack of housing that force a woman to stay in an abusive relationship." (Minnesota Advocates for Human Rights, 1996). "Economic abuse is another form of abuse in which women are the primary victims. Men have traditionally controlled and dominated the financial assets of the family, and have retained the power to make financial decisions within the family." (Baban, 2003).

Other causes

Apart from cultural and economic factors, psychological, emotional, mental health, alcohol, and drug abuse, along with other factors, influence the magnitude of domestic violence in Albania as well.

Psychological complexities influence the way people see other people. These complexities are often created in early childhood and become apparent when the person is put in a position where he/she can freely express them. The desire to dominate others, frustration, gender role misperception, the indifference toward others suffering, narcissist symptoms, over-protectionism, etc., all create an amalgam that can be compared with a bubble that bursts when the conditions are favorable. People that have been abused in their childhood might perceive violence as a good means to express their sense of right or wrong in relation to others and especially with their family members. All these elements contribute to the individual act of domestic violence, even though the person that uses violence might not be aware of them. The individual mindset is very important in analyzing the causes of domestic violence.

A considerable number of the cases of domestic violence in Albania are linked to alcohol abuse by husbands that causes them to use physical violence against their wife and children. As a 2003 report acknowledges, "[a]nother frequently cited cause of domestic violence, mentioned by 21 women, is the alcohol abuse of perpetrators." (Baban, 2003).

\section{The Law With Respect to Domestic Violence in Albania}

Tackling domestic violence is not an easy task. The Albanian Government especially in recent years has enacted different statutes in relation to this matter, in order to bring the Albanian legislation closer to the standards of the European Union. This is just a first step in the fight against domestic violence. In 2010 "[t]he European Union (EU) reports that although Albania has made progress in establishing a "legal and institutional framework" to prevent domestic violence, resources to support the laws and policies are "insufficient" at both the national and local level." (Immigration and Refugee Board of Canada, 2013). "The EU adds that this lack of resources hampers the effective implementation." (Immigration and Refugee Board of Canada, 2013).

The Albanian legislation on the prevention and fight against domestic violence has increased considerably over the years. The civil and criminal law has been amended in this process. The Family Code (in particular Art. 62), the Criminal Code (In particular Art. 124/b and 130/a), the law "On Measures Against Violence in Family Relations", as amended, law "On the Ratification of the Council of Europe Convention "On Prevention and Fight of Violence Against Women and Domestic Violence", law "On the Protection of Children's Rights", law "On Gender Equality in the Society", etc., are some examples of the legal acts that deal with aspects of domestic violence in Albania. It is almost impossible to analyze all of them in this paper; therefore our focus will be on the special law that was enacted for the sole purpose of building civil capacities to fight domestic violence in Albania.

General introduction of the law "On Measures Against Violence in Family Relations"

The law No. 9669 of 18.12.2006 "On Measures Against Violence in Family Relations", as amended (OMAVFR, Albanian Law No. 9669 (2006)), represents the most far-reaching effort that the Albanian Parliament has undertaken, to deal with the widespread problem of domestic violence in Albania. It is worth mentioning that the initiative for this law came from 20.000 citizens. It represents one of the rare cases when people in Albania exercised their constitutional right to propose laws to the Parliament. This law aims "[t]o prevent and reduce domestic violence in all its forms by appropriate legal measures" and "[t]o guarantee protection through legal measures to members of the family who are subject to domestic violence, paying particular attention to needs of children, the elderly and the disabled." (Art. 1 OMAVFR, Albanian Law No. 9669 (2006)). 
OMAVFR sets out four objectives that has to be achieved by its enactment:

1) "To set up a coordinated network of responsible authorities for protection, support and rehabilitation of victims, mitigation of consequences and prevention of domestic violence.

2) To direct efforts for the set-up of responsible structures and authorities at the central and local level in support of victims and prevention of domestic violence.

3) To empower the judiciary in taking protection measures against domestic violence.

4) To ensure/guarantee quick, affordable and simple services to the victims of domestic violence provided by courts and other law enforcement agencies in compliance to the law." (Art. 2 OMAVFR, Albanian Law No. 9669 (2006)).

Violence in the domestic setting according to article 3(1) of this law "is any act or omission of one person against another, resulting in violation of the physical, moral, psychological, sexual, social and economic integrity." Therefore, domestic violence is defined in article 3(2) as "any act of violence pursuant to point one of this one article committed between persons who are or used to be in a family relation." Family members are considered the following categories of people: "(a) Spouses or cohabitating partners or former spouses or former cohabitating partners..."

The law "On Measures against Violence in Family Relations", as amended, creates an institutional framework to deal with domestic violence. The law designs as the main responsible institution for dealing with domestic violence "the Ministry of Labor, Social Affairs and Equal Opportunities." Other responsible authorities are Local government units (i.e. Municipalities and Communes), the Ministry of the Interior, the Ministry of Health, the Ministry of Justice and the Ministry of Education and Science. All these public institutions have the responsibility to act in their respective fields of authority, when they encounter cases of domestic violence. The judiciary also plays a crucial role with regard to remedies and enforcement in cases of domestic violence.

The law "On Measures against Violence in Family Relations" assigns to every responsible institution certain additional duties. The law creates a duty for the responsible authorities to "respond to any report filed by the victim or other persons indicated by this law, for cases of violence or threat to use violence..." (Art 8 (2), OMAVFR, Albanian Law No. 9669 (2006)). The "[p]ersons who receive reporting because of their function or authority to implement this law and fail to act in its implementation shall be held administratively and/or criminally responsible..." (Art 8 (5), OMAVFR, Albanian Law No. 9669 (2006)).

The subjects that may report cases of domestic violence to the appropriate authorities (police, local authorities, public health centers, courts) are provided by article 9 of the law "On Measures Against Violence in Family Relations" and they include not only the victim but also every person that witnesses a case of domestic violence.

\section{Remedies and enforcement}

The law "On Measures against Violence in Family Relations", as amended, has created new legal remedies for victims of domestic violence. It is now easier to present a petition to the court and no fees are required to the petitioner (Art 14 (4), OMAVFR, Albanian Law No. 9669 (2006)). As a practical matter the law creates two mechanisms for the protection of victims of domestic violence. The victim can request a 1) "Protection Order" or 2) an "Emergency Protection Order". The first is the normal petition by the victim to the District Court (Family Section), to give him/her one or more of the protection measures directed towards the perpetrator of domestic violence. The second is the extraordinary petition that is more urgent in nature and is directed to the same court but is judged more rapidly.

Article 13 of the law states that the victim, his/her representative, police, prosecution office, etc., are entitled to petition the court for protection orders. "When the petition is presented by the police/prosecutor, the victim's wish to drop the case does not have an effect on the continuation of the judicial process." The law in article 10(1) provides for eighteen protective measures that the court is allowed to give in cases of domestic violence. For example "ç) prohibiting immediately the defendant (perpetrator) to be within a certain distance to the victim or members of their family as defined in article 3 point 3 of this law or as named in the order."

"The court establishes a hearing with regard to a protection order within 15 days from the filing of the petition." (Art 16 (1), OMAVFR, Albanian Law No. 9669 (2006)). On the other hand with regard to emergency protection orders, the court must reach a decision within 24 hours after receiving the petition when the victim is a minor, and in all other cases within 48 hours (Art 18 (1), OMAVFR, Albanian Law No. 9669 (2006)). When the court issues an emergency protection order, it should set within 20 days another hearing in order to verify the conditions of the emergency protection order (Art 20, OMAVFR, Albanian Law No. 9669 (2006)).

The court cannot "deny a protection order because of the existence of any other pending action involving any party. (Art 17(2), OMAVFR, Albanian Law No. 9669 (2006))". The standard of proof in cases of domestic violence is lower (preponderance of evidence) than other standard civil cases (clear and convincing evidence). The court must issue a protection order for the victim of domestic violence if (1) "[t]here is sufficient basis to believe that the defendant (perpetrator) has committed or threatened to commit an act of family violence," (Art 19 (1)(a), OMAVFR, Albanian Law No. 9669 (2006)). (2) "[t]he defendant (perpetrator) presents a direct and immediate threat to the security, health or well-being of the victim or of their family members, (Art 19 (1)(b), OMAVFR, Albanian Law No. 9669 (2006))" and (3) the "[i]ssuance of the emergency protection order is necessary to protect the security, health and welfare of the victim or their family members who are protected through this order. (Art 19 (1)(c), OMAVFR)".

The enforcement rules of protective orders are enumerated by article 23 of the law. This article provides that:

1) "The judicial decision containing the emergency protection order is considered an executive title ${ }^{1}$ from the moment it is declared by the court (or notified to the parties). The court shall issue an execution order at the same time that it issues an emergency protection order.

2) The judicial decision containing the protection order is an executive title and should therefore be carried out immediately by bailiffs according to the Civil Procedure

${ }^{1}$ The "executive title" is an Albanian civil procedure concept that basically means that a certain juridical act (for example decision) is capable of being executed by the bailiff service. In the case of a District Court decision, as a rule, it can be executed only after all the appeal procedures are finished, unless the law provides otherwise. 
Code, by police departments, local government authorities (municipality, commune) or the perpetrator voluntarily. The court shall issue an execution order at the same time that it issues a protection order..."

\section{Problems in Implementing the Legal Regulation against Domestic Violence in Albania}

The main challenge in present Albania is not the absence of legal rules against domestic violence, but the lack of efficient application of them. In a 2010 report of a NonProfitable Organization it is stressed that there still lacks the coordination between the state institutions responsible for handling domestic violence cases (Qendra për Nisma Ligjore dhe Qytetare, 2010)

In the same report it is mentioned that the Ministry of Justice should take appropriate steps to provide free legal assistance to domestic violence victims (Qendra për Nisma Ligjore dhe Qytetare, 2010). It noticed a weak role of the Prosecution Office and Local Authorities in the implementation of this law (Qendra për Nisma Ligjore dhe Qytetare, 2010). There was no case referred to the court for protective measures by these authorities (Qendra për Nisma Ligjore dhe Qytetare, 2010).

Implementing the law on domestic violence is a big challenge for the Albanian State and society. The will so far has been to influence social behavior and belief toward domestic violence, through criminalizing the acts of domestic violence. Therefore we see that the "deterrence theory of law" (Dallas, 2005) is the means used by the State to change people's attitude towards domestic violence and their exogenous preferences. It's good to keep in mind that:

"Deterrence theory provides that laws affect how persons weigh their opportunities..., but do not affect their underlying preferences. If law affects preferences through their impact on social norms, however, there is an additional means by which law can affect behavior. Law can have an "expressive function" in affecting the social meaning and values associated with certain behaviors and may have an important impact on a person's internalization of these meanings and values." (Dallas, 2005).

\section{Conclusion}

Albania is one of the developing countries of this world, where the culture of being strong and tough is still a strong value. Unfortunately many people link this quality with being violent toward others, irrespective of who they are (even family members). The need to dominate or other psychological factors play an important role in this context, along with models that one perceives as good to follow. Therefore culture is crucial in analyzing the factors that feed domestic violence. In recent years there has been a series of legal initiatives that have been enacted into law, and that deal with the question of domestic violence in Albania. But, the comparison with the EU countries shows that much needs to be done, in order to ameliorate the general situation of domestic violence, especially against children in Albania.

In an age where the family bonds between people are getting weaker, and where as a result the exercise of authoritative influence by other family members in domestic violence cases is left orphan, the consequence is that State is filling this gap (with all its good and bad aspects). We have no complete data yet, to fully analyze if this is better or worse in the long run for the society as a whole, but one thing is for sure, that violence needs to decrease rapidly.

With regard to the legal aspect of the fight against domestic violence, everything comes down to the application of the law in a State. The higher the scale of good application of the law, the better will be the situation and the faster it will improve. Albania is not any more a country without laws in this field, but is still a country with not enough good enforcement of its laws. This is one of the biggest problems, because once the law is properly enforced, we can evaluate its effectiveness and if needed the authorities can amend it. But if the enforcement of law is insufficient we cannot tell if it works or not. In the end this impacts most things that we can discuss about fighting domestic violence in modern days.

As a conclusion we want to stress that until a culture of tolerance, nonviolence, common sense and good application of laws deeply spreads its roots in Albania, there is no law that by itself can change the situation. It is pivotal in this respect, that people grow spiritually and apply every day the maxim "do to others what you would have them do to you"... We hope this is not a utopia...

\section{REFERENCES}

Albanian Law No. 9669. (2006). On Measures Against Violence in Family Relations, as amended.

Dallas, L. L. (2005). Law and Public Policy a Socioeconomic Approach, Carolina Academic Press.

McGowan, D. (2011). Developing Judgment About Practicing Law, Thomson Reuters.

TNS. (2010). Domestic Violence Against Women Report. Special Barometer 344/WAVE 73.2.

Minnesota Advocates for Human Rights. (1996). Domestic Violence in Albania.

The National Committee on Women and Family, UNICEF. (2000). Mapping of Existing Information On Domestic Violence in Albania, Albania.

Siegel, R. B. (1996) The Rule of Love: Wife Beating as Prerogative and Privacy, 105 Yale L.J. 2117.

Qendra Për Nisma Ligjore Qytetare. (2010): Zbatimi i Strategjisë Kombëtare të Barazisë Gjinore dhe Dhunës në Familje 2007-2010, si dhe Ligji Për Masa Ndaj Dhunës në Marrëdhëniet Familjare [Report: The Application of the National Strategy on Gender Balance and Violence in Family 2007-2010, and the Law On Measures Against Violence in Family Relations], Albania.

Baban, A. (2003). Domestic Violence against Women in Albania. Retrieved from http://www.unicef.org/albania/domviol_eng.pdf

Haarr, R. N., Dhamo M. (2009). Dhuna në Familje në ShqipëriSondazh Kombëtar me Bazë Popullatën [Violence in the Family in Albania-National Survey on the Population]. Immigration and Refugee Board of Canada. (2013). Retrieved from http://mdhamo.files.wordpress.com/2010/01/final-dv-survey-reportalbanian.pdf 